\title{
ARTIKEL
}

\section{TEACHER QUESTIONS IN ENGLISH CLASSROOM}

\author{
Disusun dan Diajukan oleh: \\ Angelina. N. F. Limbong
}

NIM 2123321004

Telah diverifikasi dan dinyatakan memenuhi syarat

untuk diunggah pada jurnal online

Medan, November 2017

Menyetujui

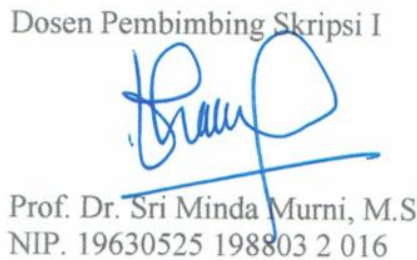

Dosen Pembimbing Skripsi II

NIP. 196305251988032016

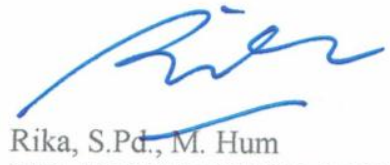

NIP. 197807172008122001

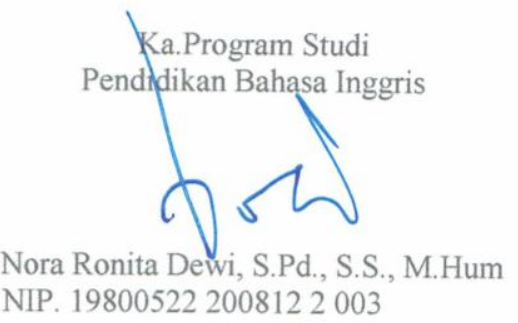




\title{
TEACHER QUESTIONS IN ENGLISH CLASSROOM
}

\author{
*Angelina. N. F. Limbong \\ **Sri Minda Murni \\ **Rika
}

\begin{abstract}
The objective of this study was to find out the levels of questions used by teacher in English classroom and revealing the underlying reasons why teacher ask questions to the students in the classroom. This study was conducted by using descriptive qualitative research design. The subjects of this study is one of English teacher who teach in eighth grade students in one of school SMP in Pakpak Bharat that is SMP N 1 Kerajaan in academic year 2016/2017. The data were collected by video recording and interviewing the English teacher. The data were analyzed by using Miles and Huberman data analysis technique. The findings of the study were shown there were four levels of questions used by the teacher in English classroom from six levels of questions based on Bloom Taxonomy in Anderson and Krathwohl, with the total of questions were 117 in two meetings. Teacher spent remembering level 56\% (66 questions), understanding level 31\% (36 questions), applying level were 4\% (5 questions), analyzing level were 9\% (10 questions), evaluating level $0 \%$ and creating level $0 \%$. From those levels, the dominance is discovered to be at the level of remembering, known as Lower Cognitive Questions (LCQ). This study also found that the underlying reasons of teacher ask questions in the classroom is to stimulate students' interest, to encourage students focus to think when students learn, to know students understanding, and to give participation when they learn. It can be concluded that the teacher's questions are as the technique of teaching.
\end{abstract}

Keywords: Teacher's Questions, Levels of Question, Reasons Asked Questions

\footnotetext{
*Graduate status

$* *$ Lecturer status
} 


\section{INTRODUCTION}

\section{Background of the Study}

Teachers play significant roles at classrooms. Teachers are not only expected to teach but also to facilitate, to guide, to model, or to evaluate students in teaching and learning activities. In teaching learning process, teachers need to pay attention to the students, pay attention to what students learn and how students learn (psychology). The intensity of learning experience can be seen from the high involvement of students in teaching and learning relationships with teachers and learning objects. If in teaching learning process, the students spend more time to listen and record the teacher's explanations; the classroom atmosphere can be said lack of adequate quality.

According to PP RI No. 19/2005 28(3), educators are learning agent who must have four types of competence, namely pedagogical competence, personal competence, professional competence, social competence. In this context, teacher competence is defined as the knowledge, skills, and attitudes that expressed in the act smart and responsibly owned by a teacher. In the case of a professional, a teacher must possess teaching skills in terms of: open and close the lesson, ask questions, provide reinforcement, and held a variety of teaching. One of teaching skills that need to be known by a teacher is a questioning skill.

Hasibuan (2008) states that questioning skills can increase student participation in learning, generate interest and curiosity of students, develop ways of thinking, ways of active learning, and can focus on the students. 
Adedoyin (2010) states that teacher's questions are of significant value for many instructional purposes, eliciting student reflection, challenging deeper students understanding and engagement in the classroom. Teacher questioning is an indispensible part of teaching process. It means that teacher's question is one important role in teaching-learning process to built language production of students. Teacher asks a lot of questions. In fact, the standard pattern in the classroom is one in which the teacher asks a questions, and one or more students respond to the questions (Richard, 2000). Then, the teacher evaluates the response.

As writer's observed, it is found that the teacher asked many questions in the classroom. Based on the observation, the teacher just asked questions spontaneously without preparing the questions before in teaching learning process. The teacher also asked the same and repeatedly questions to the students during teaching learning process. From all of questions that teacher asked, the teacher mostly use level low cognitive questions (LCQ) that is require students to recall previously acquired information. Teacher questions are one of the teaching strategies that can help students acquire the target language better. Typically, a teacher asks a question without used all of level cognitive questions. Consequently, teacher does not get and doesn't know how students comprehension exactly.

Based on the explanation above, a teacher should be aware of question level and why teacher asks the questions during teaching learning process. After knowing what the teacher should do, hopefully, the teacher can obtain or even raise students' comprehension in using the target language. Based on the above discussion, this 
study was interested in analyzing the teacher questions in English classroom at SMP N 1 Kerajaan. This study wanted to know what levels of questions were used by the teacher and the reasons teacher asked questions to students in English classroom.

\section{REVIEW OF LITERATURE}

\section{Classroom Interaction}

Classroom interaction is studied from a social interaction perspective to unearth the mechanisms teachers and students use to conduct their classroom business. This business varies from teacher-fronted activities to student group work, or teacherstudent dyadic interaction, and from mutual consultations among students to - no surprise for all of us who have spent time in classrooms - students' work of not paying attention. Language and social interaction research of classroom interaction is concerned with the classroom work participants do together in mutual interactional engagement and therefore focuses empirically on what participants make observable for each other in their interaction behavior, both in terms of how participants want to be understood and in terms of how participants understand each other.

2. The Participants in Classroom Interaction

These are the most frequent ways of organizing classroom interaction, depending on who communicates with whom:

a. Teacher - learners is established when a teacher talks to the whole class at the same time. 
b. Teacher - learner/a group of learners is conducted when the teacher refers to the whole class, but expects only one student or a group of students to answer. It is often used for evaluation of individual students.

c. Learner - learner is called 'pair work'. Students get an assignment, which they have to finish in pairs. The teacher holds the role of a consultant or adviser, helping when necessary. After the activity, he puts the pairs into a whole group and each pair reports on their work.

d. Learners - learners is called 'group work'. As with pair work, the teacher's function here is that of a consultant and individual groups report on their work as a follow-up activity.

3. Teachers Talk

Teacher talk is a kind of language the teachers use at classrooms. This can be viewed as language of instruction (Yan, 2006). At English classrooms, teachers use teacher talk to give exposure of the target language learned to students. Therefore, teacher's talk believed the function is the important roles when teachers play for language teaching and learning. As a language teacher's, teacher talk can be both in oral and written form. The oral form is the one that teachers deliver through speaking. Unlike the oral teacher talk, the written one usually appears through writing.

4. Question and Teacher's Question

Questioning is a common technique used in English language teaching. The goal is to check if the students understand what they have been taught, and to enhance 
students' involvement and to promote students' creative thinking in classroom interaction (Ennis, 1996). Questioning is one kind of teaching active procedure. It is one teaching behavior way through teachers and students' interaction, checking learning, promoting thought, consolidating knowledge, using knowledge, achieving teaching goals. Chaudron (1998, p. 125) mentions that, teachers questions constitute a primary means of engaging learners' attention, promoting verbal responses, and evaluating learners' progress. In other words, it means that teacher questions play an important role in managing classroom routines.

\section{a. Types of Teacher's Questions}

There are six levels of Bloom's Taxonomy in Anderson and Krathwohl (2001).

1) Remembering

Remembering is recognizing or recalling knowledge from memory. Remembering is when memory is used to produce or retrieve definitions, facts, or lists, or to recite previously learned information.

Examples of Remembering Questions:

What is the capital of Maine?

2) Understanding

Understanding is constructing meaning from different types of functions be they written or graphic messages or activities like interpreting, exemplifying, 
classifying, summarizing, inferring, comparing, or explaining. To answer understanding-level question, the student must go beyond recall of information.

Examples of understanding Questions:

What is the main idea that this chart presents?

3) Applying

Applying questions is carrying out or using a procedure through executing, or implementing. Applying questions require students to apply a rule or process to a problem and thereby to determine the single right answer to that problem.

Examples of Applying Questions:

In each of the following cases, which of Newton's laws is being demonstrated?

4) Analyzing

Analyzing questions is breaking materials or concepts into parts, determining how the parts relate to one another or how they interrelate, or how the parts relate to an overall structure or purpose. Analyzing questions ask students to identify reasons, uncover evidence, and reach conclusions. Following are examples of three kinds of analyzing questions.

a) To identify the motives, reasons, and/or causes for a specific occurrence:

What factors influenced the writings of Anne Frank?

b) To consider and analyze available information to reach a conclusion, inference, or generalization based on this information:

After reading this story, how would you characterize the author's background, attitude, and point of view? 
c) To analyze a conclusion, inference, or generalization to find evidence to support or refute it:

Which of the speaker's points support affirmative action?

5) Evaluating

Evaluating questions is judgments based on criteria and standards through checking and critiquing. Critiques, recommendations, and reports are some of the products that can be created to demonstrate the processes of evaluation. Evaluation questions require the student to judge the merit of an idea, a solution to a problem, or an aesthetic work.

Examples of Evaluating Questions:

How do you assess your performance at school?

6) . Creating

Creating questions are putting elements together to form a coherent or functional whole; reorganizing elements into a new pattern or structure through generating, planning, or producing. Creating requires users to put parts together in a new way, or synthesize parts into something new and different creating a new form or product. These kinds of questions also require students to produce original communications, to make predictions, or to solve problems.

Here are some examples of the different kinds of creating questions.

a) To produce original communications:

Construct a collage of pictures that represents your values and feelings. What would be a descriptive and exciting name for this video game? 
b) To make predictions:

What would the United States be like if the South had won the Civil War?

c) To solve problems:

How can we successfully raise money to fund our homeless shelter project?

b. The Reasons Why Teacher Ask Questions

Gall in Richards and Lockhard (1994) state that there are some reasons teachers asks questions in the classroom, they are:

1) To stimulate and maintain students' interest.

2) To encourage students to think and focus on the content of the lesson.

3) To clarify what a student has said.

4) To elicit particular structures or vocabulary items.

5) To check students' understanding.

6) To encourage student participation in a lesson.

\section{RESEARCH METHODOLOGY}

This study would be designed with descriptive qualitative research which describes and interprets. Data include materials the people doing the study actively record, such as interview transcripts, and participant observation field notes. In this study, the source of data would be obtainable from English teacher. Instrument to collecting data is recorder. The data would be collected by doing documentary technique. Below are the elaborations of each technique to collecting the data: 
1. Video-recording

2. Interview

\section{Techniques for Analyzing Data}

In analyzing the data of the study, this study will apply interactive models of Miles, Huberman, and Saldana (2014). Analysis model which consisted of four steps:

(1) Data collection,

(2) Data condensation,

(3) Data display,

(4) and Data verification/ conclusion.

\section{RESEARCH FINDINGS AND DISCUSSIONS}

Research findings

1. The Levels of Teacher's Question

From the first meeting found 42 questions (consist of w/h questions) in 80 minutes and the second meeting found 75 questions (consist of w/h questions) in 120 minutes. The following Table 4.1 will show the distribution of the levels of questions.

Table 4.1 Distribution of Levels of Teacher's Question in Meeting I and II

\begin{tabular}{|c|c|c|c|c|}
\hline \multirow{2}{*}{ No } & $\begin{array}{c}\text { Levels Of Questions } \\
\text { based on Bloom } \\
\text { Taxonomy in Anderson } \\
\text { and Krathwohl (2001) }\end{array}$ & Meeting I & Meeting II & Total \\
\hline 1 & Remembering Question & $24(57 \%)$ & $42(56 \%)$ & $66(56 \%)$ \\
\hline 2 & Understanding Question & $13(3 \%)$ & $23(31 \%)$ & $36(31 \%)$ \\
\hline
\end{tabular}




\begin{tabular}{|c|l|c|c|c|}
\hline 3 & Applying Question & $2(5 \%)$ & $3(4 \%)$ & $5(4 \%)$ \\
\hline 4 & Analyzing Question & $3(7 \%)$ & $7(9 \%)$ & $10(9 \%)$ \\
\hline 5 & Evaluating Question & $0(0 \%)$ & $0(0 \%)$ & $0(0 \%)$ \\
\hline 6 & Creating Question & $0(0 \%)$ & $0(0 \%)$ & $0(0 \%)$ \\
\hline \multicolumn{2}{|c|}{ Total } & 42 & 75 & 117 \\
\hline
\end{tabular}

From the table 4.1 above, it was found that the level of questions used by the teacher were Remembering Questions, Understanding Questions, Applying Questions, Analyzing Questions. From all levels of question which had been shown above, Remembering Questions were frequently used by the teacher.

2. The Underlying Reasons of Teacher Ask Questions in the Classroom

The analysis conducted to the data derived from the in depth interview showed that there are 6 reasons causing the teacher ask questions in the classroom. The 6 reasons were (1) the teacher believed that giving question can stimulate students' interest (2) the teacher believed that the question can encourage students focus to think when students learn (3) the teacher believed that the questions can motivate the students (4) the teacher believed that questions is facilitative to teacher schedule (5) the teacher believed that the question is facilitative teacher to know students understanding (6) the teacher believed that the question is the way for students to give participation when they learn.

\section{Discussions}

The research finding of this present study revealed that low cognitive questions are mostly asked by the teachers than high cognitive questions. The finding in LCQ 
category is remembering level 66 questions or 56\%, understanding level 36 questions or $31 \%$, applying level 5 question or $4 \%$, and HCQ category is analyzing level 10 questions or $9 \%$, evaluating level $0 \%$, and creating level $0 \%$. So, the high frequency of questions level is remembering, which is reach 66 questions or $56 \%$. So, it can be concluded that LCQ dominates used by the teacher. Most of questions used by the teacher were functioned as a way of checking students understanding, knowledge and comprehending. By asking low cognitive questions (LCQ) teacher can easily know students understanding of the lesson whereas high cognitive questions (HCQ) need more time for students to think and discuss.

As for research questions 2, the results from the transcript interview were shown six reasons why teacher asked questions during teaching learning process, with applied questions to students, it can help the teacher to stimulate and maintain student interest, to encourage students to think and focus on the content of the lesson, to check students understanding, and to encourage student participation in a lesson.

\section{CONCLUSIONS AND SUGGESTIONS}

Conclusions

1. Dealing with the level of teacher's questions, it was revealed that the teacher mostly used low cognitive questions than high cognitive questions. There were $107(91 \%)$ low cognitive questions and $10(9 \%)$ high cognitive questions. There were totally 117 questions that asked by the teacher in 200 minutes teaching 
learning process in English classroom of SMP N 1 kerajaan. Whereas the classifications of questions according to Bloom taxonomy in in Anderson and Krathwohl (2001); they are remembering level 56\% (66 questions), understanding level 31\% (36 questions), applying level were 4\% (5 questions), analyzing level were 9\% (10 questions), evaluating level 0\% and creating level $0 \%$. From those levels, the high frequency of questions is remembering level. From all the levels of questions, it can be concluded that remembering and understanding levels dominant used in eighth grade and it should be classify into low cognitive questions (LCQ).

2. Gall in Richards and Lockhard (1994) in their book entitled Reflective Teaching in Second Language Classroom mention six reasons: (1) To stimulate and maintain students' interest. (2) To encourage students to think and focus on the content of the lesson. (3) To clarify what a student has said. (4) To elicit particular structures or vocabulary items. (5) To check students' understanding. (6) To encourage student participation in a lesson. Based on the analysis, the reason why the teacher asks a question to the students in the classroom is because the teacher believed that giving question can stimulate students' interest, the teacher believed that the question can encourage students focus to think when students learn, the teacher believed that the question is facilitative teacher to know students understanding, and the teacher believed that the question is the way for students to give participation when they learn.

\section{Suggestions}


1) The teacher should be aware while posing the question during the teachinglearning process. The teacher should make effort to get students more interest in the questions. Teacher can provide different kinds of questions just beyond students' current level and relate the contents of questions with student's daily experience. The teacher also may provide immediate feedback which will motivate students to participate. Teacher should pay more attention to the type of questions; guiding students to think actively and apply into practice flexibly to improve students' abilities of logical thinking. The teacher should learn more the theoretical background of teacher questioning skill to build the foundation of further practices. These levels of questions in this present study can be used by the teacher in order to be reference for improving the students learning and developing teaching skill.

2) The findings of this research can be used as a reference to give better understanding for the future researcher; the next researcher may provide additional information and comparison that might be relevant to the study.

3) Further Researcher, particularly those who have the same problem and interested in conducting research, it is suggested that this study can be a reference. Hopefully, there will be any further research of how to complete this method is more effective. 


\section{REFERENCES}

Adedoyin, Omobola. 2010. An Investigation of the Effects of Teacher's Classroom Questions on The Achievements of Students in Mathematics: Case Study of Botswana Community Junior Secondary School. European Journal of Education Studies.

Anderson and Krathwohl. 2001. A Taxonomy for Learning, Teaching and Assesing: A Revision of Bloom's Taxonomy of Educational Objectives. New York: Addison Wesley Longman.

Bloom, Benjamin, ed. Taxonomy of Educational Objectives, Handbook I: Cognitive domain. New York: David Mckay.

Chaudron, Craig. 1988. Second Language Classroom: Research on Teaching and Learning, Second Edition. New York: Longman.

Cooper, M. J. 2011. Classroom Teaching Skills, $9^{\text {th }}$ edition. USA: University of Virginia

Creswell, John W. 2009. Research Design: Qualitative, quantitative, and mixed methods approaches, $3^{\text {rd }}$ edition. California: SAGE.

Devitoyani. 2013. The Analysis of Teachers' Questions at High School Classrooms of English in Jakarta. Skripsi. Jakarta: Universitas Siswa Bangsa International.

Hasibuan, J.J. 2008. Proses Belajar Mengajar. Bandung: PT. Remaja Rosdakarya.

Kathleen \& Danu.2013. Classroom questioning. Portland, OR: North West Regional Educational Laboratory.

Miles, M.B. \& Huberman, A.B. 1994. C.B. 2001. Qualitative Data Analysis. London: Sage Publication. 